\title{
Editorial
}

\section{Ocean Exchange and Circulation}

\author{
Miroslav Gačić and Manuel Bensi *D \\ National Institute of Oceanography and Experimental Geophysics, Borgo Grotta Gigante 42-C, I-34010 Trieste, \\ Italy; mgacic@inogs.it \\ * Correspondence: mbensi@inogs.it
}

Received: 12 March 2020; Accepted: 18 March 2020; Published: 20 March 2020

check for updates

\begin{abstract}
The great spatial and temporal variability, which characterizes the marine environment, requires a huge effort to be observed and studied properly since changes in circulation and mixing processes directly influence the variability of the physical and biogeochemical properties. A multi-platform approach and a collaborative effort, in addition to optimizing both data collection and quality, is needed to bring the scientific community to more efficient monitoring and predicting of the world ocean processes. This Special Issue consists of nine original scientific articles that address oceanic circulation and water mass exchange. Most of them deal with mean circulation, basin and sub-basin-scale flows, mesoscale eddies, and internal processes (e.g., mixing and internal waves) that contribute to the redistribution of oceanic properties and energy within the ocean. One paper deals with numerical modelling application finalized to evaluate the capacity of coastal vegetated areas to mitigate the impact of a tsunami. The study areas in which these topics are developed include both oceanic areas and semi-enclosed seas such as the Mediterranean Sea, the Norwegian Sea and the Fram Strait, the South China Sea, and the Northwest Pacific. Scientific findings presented in this Special Issue highlight how a combination of various modern observation techniques can improve our understanding of the complex physical and biogeochemical processes in the ocean.
\end{abstract}

Keywords: mesoscale eddies; deep-sea thermohaline variability; dense-water formation; picoplankton distribution; glider; floats; high-frequency radar; moorings; tsunami; Kuroshio bifurcation; internal waves

\section{Introduction}

The oceanic circulation shows great spatial and temporal variability that requires a huge effort to be observed and studied properly [1]. Satellites, autonomous platforms, fixed point observatories located in key regions of the world ocean, and repeated hydrographic surveys are a means to collect new data. However, when the spatial and temporal resolution is not adequately resolved, numerical models can complement or compensate for the lack of information needed for the observation of the most complex oceanic dynamics and processes.

This Special Issue collects a series of scientific articles (Table 1) that address oceanic circulation and water mass exchange. The study areas in which these topics are developed are the Mediterranean Sea, the Norwegian Sea and the Fram Strait, the South China Sea, and the Northwest Pacific. The papers deal with the oceanic circulation generated by wind and/or density gradients, which contributes to the exchange of water between different parts of the ocean or between marginal seas and adjacent ocean areas. These processes develop at different spatial and temporal scales. Other than mean circulation, basin and sub-basin-scale flows, mesoscale eddies and internal processes (e.g., mixing induced by bottom roughness, internal waves) also contribute to the redistribution of oceanic properties and energy within the ocean, but they are not always correctly taken into consideration. Thermohaline ocean circulation is driven by winter convection and dense water formation processes, which are directly influenced by weather conditions. Subsequently, long-term and climatic changes in circulation 
and vertical mixing processes directly influence the variability of the ocean biogeochemical properties. A special role in trapping and/or transporting the biogeochemical properties of seawater is played by travelling eddies; however, this is yet to be quantified. The scientific papers included in this Special Issue try to provide new evidence related to the processes associated with the circulation and mixing in both oceanic areas and semi-enclosed seas.

Table 1. Summary of the nine papers published in the Special Issue "Ocean Exchange and Circulation" in the Water Journal (https://www.mdpi.com/journal/water/special_issues/Ocean_Exchange_and_Circulation).

\begin{tabular}{|c|c|c|c|}
\hline Keywords & Authors & Title & Study Area \\
\hline $\begin{array}{c}\text { remote sensing; } \\
\text { high-frequency radar; } \\
\text { Malta-Sicily Channel; Malta } \\
\text { Sicily Gyre; surface circulation }\end{array}$ & $\begin{array}{c}\text { Reyes-Suarez, N.; Cook, M.; Gačić, } \\
\text { M.; Paduan, J.; Drago, A.; } \\
\text { Cardin, V. }\end{array}$ & $\begin{array}{l}\text { Sea Surface Circulation } \\
\text { Structures in the } \\
\text { Malta-Sicily Channel } \\
\text { from Remote Sensing } \\
\text { Data. }\end{array}$ & $\begin{array}{l}\text { Mediterranean Sea, } \\
\text { Malta-Sicily Channel }\end{array}$ \\
\hline $\begin{array}{c}\text { picoplankton community; } \\
\text { deep-sea; Southern Adriatic; } \\
\text { Mediterranean Sea }\end{array}$ & $\begin{array}{l}\text { Šantić, D.; Kovačević, V.; Bensi, M.; } \\
\text { Giani, M.; Vrdoljak Tomaš, A.; } \\
\text { Ordulj, M.; Santinelli, C.; } \\
\text { Šestanović, S.; Šolić, M.; Grbec, B. }\end{array}$ & $\begin{array}{c}\text { Picoplankton } \\
\text { Distribution and Activity } \\
\text { in the Deep Waters of the } \\
\text { Southern Adriatic Sea. } \\
\text { Water } 2019\end{array}$ & $\begin{array}{l}\text { Mediterranean Sea, } \\
\text { Adriatic Sea }\end{array}$ \\
\hline $\begin{array}{c}\text { Mediterranean Sea; drifters; } \\
\text { sub-basin-scale eddies; gliders }\end{array}$ & $\begin{array}{c}\text { Mauri, E.; Sitz, L.; Gerin, R.; } \\
\text { Poulain, P.; Hayes, D.; Gildor, H. }\end{array}$ & $\begin{array}{l}\text { On the Variability of the } \\
\text { Circulation and Water } \\
\text { Mass Properties in the } \\
\text { Eastern Levantine Sea } \\
\text { between September } \\
\text { 2016-August } 2017\end{array}$ & $\begin{array}{l}\text { Mediterranean Sea, } \\
\text { Levantine Sea }\end{array}$ \\
\hline $\begin{array}{l}\text { Sicily Channel; spatial and } \\
\text { temporal variability; } \\
\text { mesoscale eddies }\end{array}$ & $\begin{array}{c}\text { Menna, M.; Poulain, P.; Ciani, D.; } \\
\text { Doglioli, A.; Notarstefano, G.; } \\
\text { Gerin, R.; Rio, M.; Santoleri, R.; } \\
\text { Gauci, A.; Drago, A. }\end{array}$ & $\begin{array}{l}\text { New Insights of the } \\
\text { Sicily Channel and } \\
\text { Southern Tyrrhenian Sea } \\
\text { Variability. }\end{array}$ & $\begin{array}{c}\text { Mediterranean Sea, Sicily } \\
\text { Channel and the } \\
\text { Tyrrhenian Sea }\end{array}$ \\
\hline $\begin{array}{l}\text { Levantine intermediate water } \\
\text { formation; Levantine deep } \\
\text { water formation; Rhodes Gyre; } \\
\text { boundary currents; heat fluxes; } \\
\text { Argo floats; dense water } \\
\text { formation }\end{array}$ & $\begin{array}{l}\text { Kubin, E.; Poulain, P.; Mauri, E.; } \\
\text { Menna, M.; Notarstefano, G. }\end{array}$ & $\begin{array}{l}\text { Levantine Intermediate } \\
\text { and Levantine Deep } \\
\text { Water Formation: An } \\
\text { Argo Float Study from } \\
2001 \text { to } 2017\end{array}$ & $\begin{array}{l}\text { Mediterranean Sea, } \\
\text { Levantine Sea }\end{array}$ \\
\hline $\begin{array}{l}\text { Fram Strait; deep-sea } \\
\text { thermohaline variability; slope } \\
\text { currents; wind-induced } \\
\text { processes; shelf-slope } \\
\text { dynamics }\end{array}$ & $\begin{array}{l}\text { Bensi, M.; Kovačević, V.; Langone, } \\
\text { L.; Aliani, S.; Ursella, L.; Goszczko, } \\
\text { I.; Soltwedel, T.; Skogseth, R.; } \\
\text { Nilsen, F.; Deponte, D.; Mansutti, } \\
\text { P.; Laterza, R.; Rebesco, M.; Rui, L.; } \\
\text { Lucchi, R.; Wåhlin, A.; Viola, A.; } \\
\text { Beszczynska-Möller, A.; } \\
\text { Rubino, A. }\end{array}$ & $\begin{array}{l}\text { Deep Flow Variability } \\
\text { Offshore South-West } \\
\text { Svalbard (Fram Strait) }\end{array}$ & $\begin{array}{l}\text { Fram Strait; Greenland } \\
\text { Sea; Barents Sea }\end{array}$ \\
\hline $\begin{array}{l}\text { Kuroshio bifurcation; Luzon } \\
\text { Strait; SOM; temporal and } \\
\text { spatial variation; sea surface } \\
\text { temperature; mesoscale eddy }\end{array}$ & Sun, R.; Zhai, F.; Gu, Y. & $\begin{array}{l}\text { The Four Patterns of the } \\
\text { East Branch of the } \\
\text { Kuroshio Bifurcation in } \\
\text { the Luzon Strait. }\end{array}$ & $\begin{array}{c}\text { Northwest Pacific, Luzon } \\
\text { Strait }\end{array}$ \\
\hline $\begin{array}{l}\text { complex processes; eddies; } \\
\text { mobility indicators; splitting } \\
\text { and merging; community } \\
\text { division; South China Sea }\end{array}$ & $\begin{array}{c}\text { Wang, H.; Du, Y.; Liang, F.; Sun, Y.; } \\
\text { Yi, J }\end{array}$ & $\begin{array}{c}\text { A Census of the } \\
\text { 1993-2016 Complex } \\
\text { Mesoscale Eddy } \\
\text { Processes in the South } \\
\text { China Sea. Water } 2019\end{array}$ & South China Sea \\
\hline $\begin{array}{l}\text { tsunami waves; numerical } \\
\text { simulation; wave run-up; flow } \\
\text { structure; coastal vegetation }\end{array}$ & $\begin{array}{c}\text { Zhang, H.; Zhang, M.; Xu, T.; } \\
\text { Tang, J. }\end{array}$ & $\begin{array}{c}\text { Numerical Investigations } \\
\text { of Tsunami Run-Up and } \\
\text { Flow Structure on } \\
\text { Coastal Vegetated } \\
\text { Beaches }\end{array}$ & Theoretical study \\
\hline
\end{tabular}

\section{Oceanic Circulation and Mesoscale Features: Experimental and Modelling Approaches}

One paper in this Special Issue represents an example of numerical modelling application, displayed by Zhang et al. [2], where the authors study the interaction of the ocean with the coastal area: in fact, coastal areas are the most densely populated and urbanized, but they are also complex and delicate environments. In coastal areas, waves have a strong impact that can be devastating and produce great damage as well as the loss of human lives. In this case, prevention, through the application of numerical models for case studies, e.g., the impact of tsunami waves, is very important. 
A depth-integrated numerical model was established to simulate wave propagation in a coastal region with and without forest cover, which could be considered buffer zones able to mitigate the impacts from tsunami waves over coastal areas. Overall, these findings provide cost-effective natural strategies to improve the effectiveness of vegetated bioshields against tsunami hazards.

Other papers in this Special Issue reflect the large interest and importance of mesoscale eddies in a number of semi-enclosed seas of the world ocean. A detailed census of mesoscale eddies and their generation and migration within the South China Sea is presented by Wang et al. [3]. A combined use of satellite measurement data and Hybrid Coordinate Ocean Model (HYCOM) reanalysis data, together with the self-organizing map (SOM) method, was used to investigate the east branch of the Kuroshio bifurcation where four coherent patterns associated with mesoscale eddies in the Pacific Ocean were found [4]. On the other hand, generation mechanisms like wind curl and dense water flow of the mesoscale eddies in the Ionian Sea (central Mediterranean) were addressed and some comparisons between the two forcing mechanisms were discussed in the paper by Menna et al. [5]. The Sicily Channel, in between the eastern and western Mediterranean basins, is another area characterized by large mesoscale variability and water mass exchanges that was analyzed in the paper by Reyez-Suarez et al. [6]. In this paper, data obtained by the High Frequency (HF) radar enabled authors to identify semi-permanent gyres, which were clearly evident from altimetry data also. By using satellite chlorophyll data, authors showed the signal present in the phytoplankton coinciding with altimetry or HF circulation data. Geostrophic flow obtained from the altimetry data fits very well with the HF radar data averaged over a few weeks. The paper presented by Menna et al. [5] deals with such variability more or less in the same area using a combination of long-term, time-series altimetry data, Sea Surface Temperature (SST), and remotely sensed wind data in order to study the seasonal and multiannual variability of mesoscale structures. Wind data allowed the authors to discuss in detail the generation mechanism of mesoscale eddies and the importance of wind stress and wind stress vorticity fields on their seasonal variability.

The role of mesoscale eddies in enhancing the primary production both at the open ocean $[7,8]$ and in semi-enclosed seas (e.g., $[9,10])$ has been extensively addressed in oceanographic literature ever since the mid-1990s. There is also an important interaction between mesoscale eddies and plankton spatial patterns, and thus the biological features in the ocean are, to a large degree, conditioned by these circulation features [11]. In this issue, picoplankton biomass, distribution, and activity were addressed in the paper by Šantić et al. [12], where the authors used data collected during two Eurofleets2 cruises gathered in the Adriatic Sea (eastern Mediterranean) to compare pre- and post-winter convection phases. The Adriatic Sea is, in fact, one of the main dense water formation sites in the Mediterranean Sea [13], where long-term variability and climatic shifts can produce important effects on the overall circulation of this marginal sea, with possible repercussions on the global thermohaline circulation also [14]. Indeed, despite being a marginal sea, the large-scale dynamical effects linked to the interaction between the Mediterranean water outflow from the Strait of Gibraltar and the Atlantic Ocean has always been the subject of study [15]. The so-called "Meddies", for example, are lenses of warm and salty Mediterranean Water that travel through the North Atlantic at depths between $~ 500$ and $1500 \mathrm{~m}$. They are typically $40-100 \mathrm{~km}$ in diameter with their core being 500-1000 $\mathrm{m}$ thick [16]. Signatures of the timing of Mediterranean outflow water activity are recorded in the depositional sediment, revealing how the addition of the warm saline water to the cooler less-salty waters of the Atlantic was related to climate change, deep ocean circulation, and plate tectonics [17].

Furthermore, the deep flow variability and the dynamics related to internal waves are analyzed in the paper published by Bensi et al. [18], where the authors take into account the bottom current flows and thermohaline variability in the eastern part of the Fram Strait, which is a crossroad of waters between the North Atlantic and the Arctic Ocean. Starting from a detailed analysis of time series data collected through deep-sea oceanographic moorings, the authors discuss the ocean-atmosphere interactions in a region where they are particularly intense, and where they lead to multiple oceanographic processes, like shelf-slope dynamics, deep water variability through the mixing of Polar and Atlantic waters, 
as well as sea ice and dense water formation. A strong eddy activity was observed at $1000 \mathrm{~m}$ depth in the Fram Strait, associated with the passage of topographically trapped waves enhanced by the atmospheric events particularly intense in the winter season.

A multiplatform approach is an efficient experimental tool to study oceanic features and their evolution in time and space, and this is illustrated successfully in a series of papers in this issue. Based on the analyses of drifters, floats, altimetry, and glider data, the paper by Mauri et al. [19] focuses on quasi-permanent features, i.e., meandering structures and eddies/gyres, in the easternmost part of the Mediterranean Sea [19], which is also a region where the Levantine intermediate water originates from and starts its travel westwards, contributing to the generation of the necessary pre-conditions for the dense water formation in the Aegean, Adriatic, and West Mediterranean basins [20]. In particular, by the visual inspection of more than 800 vertical profiles of temperature, salinity, and potential density gathered from ARGO floats, Kubin et al. [20] detected the timing and evolution, of the Levantine intermediate and deep waters, revealing that, in some conditions, the algorithm used for the detection of the mixed layer depth can underestimate it during winter convection events.

\section{Conclusions}

This Special Issue contributes to highlight and discuss topics related to the oceanography of semi-enclosed seas and the open ocean. An important number of articles address the theme of mesoscale eddies and their generation/variability by external or internal forcing. In this Special Issue, the effects of mesoscale circulation on biological processes are also covered. The approach to these studies used a broad spectrum of modern measurement techniques that allow for a high temporal and spatial resolution; in this context, fixed-point observations, remote sensing techniques, data from gliders, floats, and drifters are used to a large extent. The characteristics of the circulation on larger spatial scales were also addressed and some important aspects, such as the thermohaline variability of deep layers or the formation of dense water, have been discussed. Future works should be more oriented towards an increasingly enhanced combination of numerical modelling data assimilation techniques and experimental data. Particularly promising results could be obtained from the assimilation of high-frequency radar data, which can also be used very efficiently in submesoscale vortex studies. A multi-platform approach, in addition to optimizing data collection-in terms of quality, also-will bring the scientific community to more efficient monitoring and better predictions of the world ocean processes. This must be a collaborative effort, useful to optimize and integrate ocean observing systems, sensor deployment, and usage [21]. Only with this approach can the scientific community take a step forward in the understanding of climate variability and the anthropogenic effect.

Author Contributions: the two authors contributed equally to the preparation of the article. Conceptualization, M.G. and M.B.; writing—original draft preparation, M.G. and M.B.; writing—review and editing, M.G. and M.B; All authors have read and agreed to the published version of the manuscript.

Funding: This research received no external funding.

Acknowledgments: Thanks are due to the editors of the journal, as well as to the authors who contributed with their articles to the Special Issue. Finally, special thanks go to the anonymous reviewers, who have contributed efficiently to improve the quality of the articles.

Conflicts of Interest: The authors declare no conflict of interest.

\section{References}

1. Stammer, D.; Wunsch, C.; Giering, R.; Eckert, C.; Heimbach, P.; Marotzke, J.; Adcroft, A.; Hill, C.N.; Marshall, J. Global ocean circulation during 1992-1997, estimated from ocean observations and a general circulation model. J. Geophys. Res. Oceans 2002, 107, 1-1-1-27. [CrossRef]

2. Zhang, H.; Zhang, M.; Xu, T.; Tang, J. Numerical Investigations of Tsunami Run-Up and Flow Structure on Coastal Vegetated Beaches. Water 2018, 10, 1776. [CrossRef]

3. Wang, H.; Du, Y.; Liang, F.; Sun, Y.; Yi, J. A Census of the 1993-2016 Complex Mesoscale Eddy Processes in the South China Sea. Water 2019, 11, 1208. [CrossRef] 
4. Sun, R.; Zhai, F.; Gu, Y. The Four Patterns of the East Branch of the Kuroshio Bifurcation in the Luzon Strait. Water 2018, 10, 1822. [CrossRef]

5. Menna, M.; Poulain, P.-M.; Ciani, D.; Doglioli, A.; Notarstefano, G.; Gerin, R.; Rio, M.-H.; Santoleri, R.; Gauci, A.; Drago, A. New Insights of the Sicily Channel and Southern Tyrrhenian Sea Variability. Water 2019, 11, 1355. [CrossRef]

6. Reyes Suarez, N.C.; Cook, M.S.; Gačić, M.; Paduan, J.D.; Drago, A.; Cardin, V. Sea Surface Circulation Structures in the Malta-Sicily Channel from Remote Sensing Data. Water 2019, 11, 1589. [CrossRef]

7. Falkowski, P.G.; Ziemann, D.; Kolber, Z.; Bienfang, P.K. Role of eddy pumping in enhancing primary production in the ocean. Nature 1991, 352, 55-58. [CrossRef]

8. McGillicuddy, D.J.; Anderson, L.A.; Bates, N.R.; Bibby, T.; Buesseler, K.O.; Carlson, C.A.; Davis, C.S.; Ewart, C.; Falkowski, P.G.; Goldthwait, S.A.; et al. Eddy/Wind Interactions Stimulate Extraordinary Mid-Ocean Plankton Blooms. Science 2007, 316, 1021-1026. [CrossRef] [PubMed]

9. Crawford, W.R.; Brickley, P.J.; Thomas, A.C. Mesoscale eddies dominate surface phytoplankton in northern Gulf of Alaska. Prog. Oceanogr. 2007, 75, 287-303. [CrossRef]

10. Lin, I.-I.; Lien, C.-C.; Wu, C.-R.; Wong, G.T.F.; Huang, C.-W.; Chiang, T.-L. Enhanced primary production in the oligotrophic South China Sea by eddy injection in spring. Geophys. Res. Lett. 2010, 37. [CrossRef]

11. McGillicuddy, D.J. Mechanisms of Physical-Biological-Biogeochemical Interaction at the Oceanic Mesoscale. Annu. Rev. Mar. Sci. 2016, 8, 125-159. [CrossRef] [PubMed]

12. Šantić, D.; Kovačević, V.; Bensi, M.; Giani, M.; Vrdoljak Tomaš, A.; Ordulj, M.; Santinelli, C.; Šestanović, S.; Šolić, M.; Grbec, B. Picoplankton Distribution and Activity in the Deep Waters of the Southern Adriatic Sea. Water 2019, 11, 1655. [CrossRef]

13. Malanotte-Rizzoli, P.; Artale, V.; Borzelli-Eusebi, G.L.; Brenner, S.; Crise, A.; Gacic, M.; Kress, N.; Marullo, S.; Ribera d'Alcalà, M.; Sofianos, S.; et al. Physical forcing and physical/biochemical variability of the Mediterranean Sea: a review of unresolved issues and directions for future research. Ocean Sci. 2014, 10, 281-322. [CrossRef]

14. Robinson, A.R.; Leslie, W.G.; Theocharis, A.; Lascaratos, A. Mediterranean Sea Circulation. In Encyclopedia of Ocean Sciences; Elsevier: Amsterdam, The Netherlands, 2001; pp. 1689-1705. ISBN 978-0-12-227430-5.

15. Özgökmen, T.M.; Chassignet, E.P.; Rooth, C.G.H. On the Connection between the Mediterranean Outflow and the Azores Current. J. Phys. Oceanogr. 2001, 31, 461-480. [CrossRef]

16. Richardson, P.L.; Bower, A.S.; Zenk, W. A census of Meddies tracked by floats. Prog. Oceanogr. 2000, 45, 209-250. [CrossRef]

17. Hernández-Molina, F.J.; Stow, D.A.V.; Alvarez-Zarikian, C.A.; Acton, G.; Bahr, A.; Balestra, B.; Ducassou, E.; Flood, R.; Flores, J.-A.; Furota, S.; et al. Onset of Mediterranean outflow into the North Atlantic. Science 2014, 344, 1244-1250. [CrossRef] [PubMed]

18. Bensi, M.; Kovačević, V.; Langone, L.; Aliani, S.; Ursella, L.; Goszczko, I.; Soltwedel, T.; Skogseth, R.; Nilsen, F.; Deponte, D.; et al. Deep Flow Variability Offshore South-West Svalbard (Fram Strait). Water 2019, 11, 683. [CrossRef]

19. Mauri, E.; Sitz, L.; Gerin, R.; Poulain, P.-M.; Hayes, D.; Gildor, H. On the Variability of the Circulation and Water Mass Properties in the Eastern Levantine Sea between September 2016-August 2017. Water 2019, 11, 1741. [CrossRef]

20. Kubin, E.; Poulain, P.-M.; Mauri, E.; Menna, M.; Notarstefano, G. Levantine Intermediate and Levantine Deep Water Formation: An Argo Float Study from 2001 to 2017. Water 2019, 11, 1781. [CrossRef]

21. Pearlman, J.; Bushnell, M.; Coppola, L.; Karstensen, J.; Buttigieg, P.L.; Pearlman, F.; Simpson, P.; Barbier, M.; Muller-Karger, F.E.; Munoz-Mas, C.; et al. Evolving and Sustaining Ocean Best Practices and Standards for the Next Decade. Front. Mar. Sci. 2019, 6, 277. [CrossRef]

(C) 2020 by the authors. Licensee MDPI, Basel, Switzerland. This article is an open access article distributed under the terms and conditions of the Creative Commons Attribution (CC BY) license (http://creativecommons.org/licenses/by/4.0/). 